\title{
PENENTUAN SEBARAN HIPOSENTER GUNUNGAPI MERAPI BERDASARKAN DATA GEMPA VULKANIK TAHUN 2006
}

\author{
Oleh: \\ Romsiyatin $^{1}$, Abdul Basid ${ }^{2}$
}

\begin{abstract}
ABSTRAK: Gunungapi Merapi merupakan Gunungapi yang termuda dalam kumpulan gunung berapi di bagian selatan Pulau Jawa. Gunungapi Merapi merupakan gunungapi tipe strato yang aktif hingga saat ini. Aktifitasnya diduga mulai pada masa pleistocene atas (kurang lebih 1,5 juta tahun yang lalu). Gempa vulkanik merupakan gempa yang terjadi akibat aktivitas gunungapi. Hal ini disebabkan oleh pergerakan magma ke atas di dalam gunungapi. Penelitian ini bertujuan untuk mengetahui karakterisik gempa vulkanik Gunung Merapitahun 2006, mengetahui spectral and time frequency analysis, arrival time, dan letak hiposenter serta mengetahui mekanisme sumber gempa vulkanik Gunung Merapi tahun 2006.

Prinsip dari penelitian ini dilakukan dengan menganalisis data gempa vulkanik tahun 2006 yang berupa data sekunder dari data hasil rekaman (seismogram) Gunung Merapi pada 4 stasiun seismometer yaitu stasiun Pusunglondon, Klatakan, Deles, Plawangan. Data gempa yang berbentuk GCF diolah dengan menggunakan software Seismo Volcanalysis, Scream 44, Hypoellipse dan Matlab.

Data seismik tahun 2006 diketahui bahwa gejala awal letusan G. Merapi dimulai dengan munculnya gempa-gempa vulkanik (VTA maupun VTB) pada awal Maret dan puncaknya terjadi pada pertengahan April 2006. Berdasarkan hypocenter dari beberapa gempa VA dan VB yang terjadi pada tahun 2005/2006, dapat disimpulkan bahwa pusat gempa yang berada pada kedalaman lebih dari 1 $\mathrm{km}$ dari puncak tidak berbeda dengan hypocenter gempa VA dan VB tahun-tahun sebelumnya, tetapi untuk gempa-gempa yang dangkal hypocenter-nya cenderung bergeser ke arah tenggara. Dimana pada kedalaman 1-2 km merupakan kedalaman kantung magma dan untuk dapur magma pada G. Merapi sendiri berada pada jarak $6 \mathrm{~km}$ dari puncak. Dimana Gempa vulkanik sendiri merupakan representasi dari proses peretakan batuan (cracking) sebagai akibat desakan magma dari dalam.
\end{abstract}

Kata kunci : Gunung Merapi, Gempa Vulkanik, Spectral and Time Frequency Analysis, Arrival Time, Hypocenter.

\begin{abstract}
Merapi volcano is the youngest volcanoes in southern java island. Merapi volcano is strato volcano that active till today. Its activity supposed began at up Pleistocene (1,5 million years ago). Volcanic earthquake is one of matter that caused by volcano. This happened because magmatic movement inside volcano. This research aimed to know characteristic volcanic earthquake of merapi volcano at 2006, know spectral and time frequency analysis, arrival time and location of hypocenter also to know mechanism of Merapi volcanic earthquake at 2006.

Principles from this research is conducted by analyzing volcanic earthquake data at 2006 that consist secondary data from recording data (seismograph) volcano Merapi on 4 stations seismometer are Pusunglondon station, klatakan, deles and Plawangan. The earthquake data that formed CGF processed using Seismo volcanalysis, Scream 44 and Matlab software.

Seismicity data at 2006 known that first sign of merapi eruption began with appearing volcanic earthquakes (VTA although VTB) at the beginning of march and the peak happened at the middle of april 2006. Base on hypocenter from some VA earthquake and VB earthquake that happened at 2005/2006, it can be concluded that the center of earthquake that located on depth more than $1 \mathrm{~km}$ from peak is not different with hypocenter of VA and VB earthquake at years before, but for the earthquake with shallow hypocenter inclined to move to southern. Where on 1-2 km depth is the depth of magma pocket and magma stove on Merapi volcano its self located at range $6 \mathrm{~km}$ from the
\end{abstract}

1,2 Jurusan Fisika Fakultas Sains dan Teknologi UIN Maliki Malang

( ${ }^{1}$ Alamat koresponden: Email: Atin_Ziy26@ymail.com) 
peak. Where the volcanic earthquake is representation from rock cracking processed caused magma pressure from inside.

Keyword : Merapi Volcano, Volcanic earthquake, Spectral and Time Frequency Analysis, Arrival Time, Hypocenter.

\section{PENDAHULUAN}

Indonesia merupakan daerah yang memiliki gunungapi paling aktif di dunia. Banyaknya gunungapi di Indonesia adalah konsekuensi geologis dari posisi geografis yang terletak antara pertemuan tiga lempeng tektonik besar yaitu lempeng Indo-Australia, lempeng benua Eurasia dan lempeng Pasifik. Di bagian timur wilayah Indonesia terjadi pertemuan 3 lempeng (Triple Junction) sehingga seismisitasnya salah satu yang paling aktif di dunia. Indonesia termasuk dalam daerah Sabuk Api Pasifik (Ring of Fire), yaitu wilayah melingkar dimana batas-batas lempeng bertemu yang mengakibatkan munculnya banyak gunungapi dan zona seismik aktif.

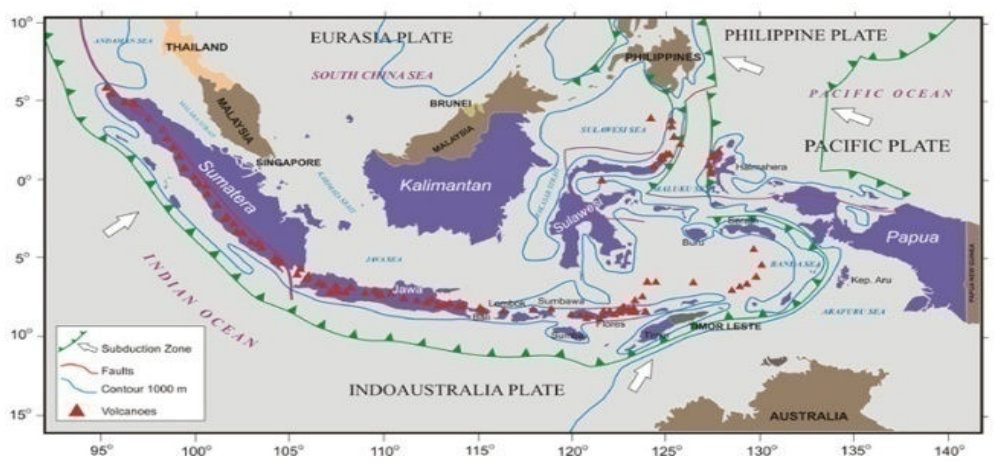

Gambar 1. Peta tektonik Indonesia dan sebaran lokasi gunungapi (http://www.merapi.bgl.esdm.go.id )

Gunungapi Merapi merupakan Gunungapi yang termuda dalam kumpulan gunung berapi di bagian selatan Pulau Jawa. Gunung ini terletak di zona subduksi, dimana Lempeng Indo-Australia terus bergerak ke bawah Lempeng Eurasia terletak pada koordinat $7^{\circ} 32,5^{\prime}$ LS dan $110^{\circ} 26,5^{\prime}$ BT. Gempa vulkanik merupakan gempa yang terjadi akibat aktivitas gunungapi. Hal ini disebabkan oleh pergerakan magma ke atas di dalam gunungapi. Ketika magma bergerak ke permukaan, ia akan memecahkan batu-batuan yang dilewati serta mengakibatkan getaran berkepanjangan yang dapat bertahan dari beberapa menit hingga beberapa hari. Metode seismik merupakan salah satu dari metode yang digunakan pada pengamatan gunungapi dalam bentuk gelombang seismik.

\section{KAJIAN TEORI}

\section{A. Pengertian Gelombang}

Gelombang adalah perambatan suatu energi, yang mampu memindahkan partikel ke tempat lain sesuai dengan arah perambatannya. Gelombang seismik merupakan 
gelombang yang menjalar di dalam bumi yang disebabkan karena adanya deformasi struktur di bawah bumi akibat adanya tekanan ataupun tarikan karena sifat keelastisitasan bumi. (Tjia, 1993)

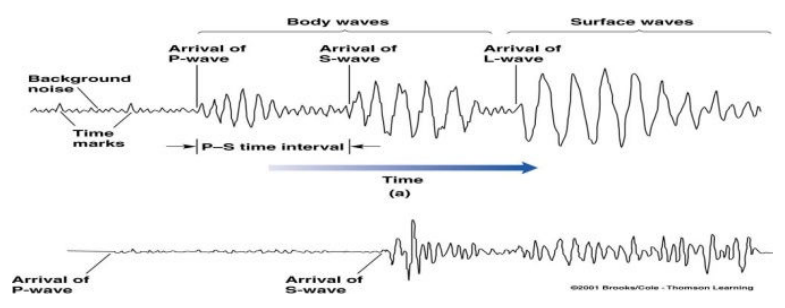

Gambar 2 jenis gelombang (Hendrajaya,1990)

\section{B. Teori Pencuplikan}

Pada pencuplikan sering terjadi peristiwa aliasing, keadaan ini terjadi disebabkan oleh frekuensi pencuplikannya terlalu rendah dari frekuensi gelombang seismik, sehingga mengakibatkan hilangnya informasi dari sinyal yang diamati.

Untuk meminimalkan terjadinya aliasing saat pencuplikan terlebih dahulu frekuensi cuplikannya ditentukan melalui hubungan:

$$
f_{n=\frac{1}{\Delta t}}
$$

Dimana $\Delta t$ adalah selang waktu pencuplikan dan $f_{n}$ adalah frekuensi pencuplikan. Selanjutnya, menentukan $f_{N}$, frekuensi nyquist yang besarnya sama dengan setengah dari frekuensi pencuplikan $f_{n}$.

$$
f_{N}=\frac{1}{2 \Delta t}
$$

\section{Transformasi Fourier}

Suatu parameter fisis yang berkaitan erat dengan fenomena geofisika adalah frekuensi. Parameter inilah yang menjadi pusat informasi dalam analisis karakteristik sinyal seismik suatu gunung api. Oleh karena itu, untuk mempermudah analisis sinyal tersebut diperlukan suatu metode yang berfungsi mengubah domain waktu ke dalam domain frekuensi yaitu Transformasi Fourier.

Jika kita memiliki sinyal $x(t)$ maka pasangan transformasi Fouriernya adalah $X(\omega)$ dengan $\omega=2 \pi f$

$$
X(\omega)=\int_{-\infty}^{\infty} x(t) e^{-i \omega t} d t
$$

Apabila $x(t)$ adalah gelombang yang terpisah menjadi beberapa gelombang sinus dan $X(\omega)$ adalah transformasi Fourier dari $x(t)$ dan $=\sqrt{-1}$, maka persamaan 2.3 dapat dituliskan kembali sebagai berikut:

$$
\begin{gathered}
X(\omega)=\int_{-\infty}^{\infty} x(t) \cos (\omega t) d t-i \int_{-\infty}^{\infty} x(t) \sin (\omega t) d t \\
=\operatorname{Re}[X(\omega)]-i \operatorname{Im}[X(\omega)] \\
=|X(\omega)| e^{i \varphi(\omega)}
\end{gathered}
$$

Sehingga diperoleh persamaan spectrum amplitude yaitu:

$$
|X(\omega)|=\sqrt{(\operatorname{Re}[X(\omega)])^{2}+(\operatorname{Im}[X(\omega)])^{2}}
$$

Dan persamaan spectrum fasa 


$$
\varphi[\omega]=\tan ^{-1}\left(-\frac{\operatorname{Im}[X(\omega)]}{\operatorname{Re}[X(\omega)]}\right)
$$

Sedangkan invers dari transformasi Fourier didefinisikan sebagai:

$$
x(t)=\int_{-\infty}^{\infty} X(\omega) e^{i \omega t} d \omega
$$

Sehingga kedua fungsi tersebut dinyatakan sebagai pasangan transformasi Fourier

$$
H(\omega) \Leftrightarrow h(t)
$$

Analisis dengan menggunakan prinsip metode transformasi Fourier ini dikenal dengan analisis spectral. Pada analisis spectral ini menggunakan seluruh bentuk sinyal sehingga jika terjadi kesalahan informasi akan mudah dihindari dengan pengukuran titiktitik dalam domain waktu.

\section{Perhitungan Hiposenter}

Salah satu metode untuk menentukan hiposenter adalah dengan analisis beda waktu tiba sinyal seismik yang datang pada beberapa stasiun. Jika menggunakan banyak stasiun, perlu diketahui terlebih dahulu factor $\mathrm{k}$ (koefisien jarak) dari gunung. Dasar perhitungannya adalah dengan menggunakan rumus perhitungan sebagai berikut: (Siswowidjoyo, S.1981)
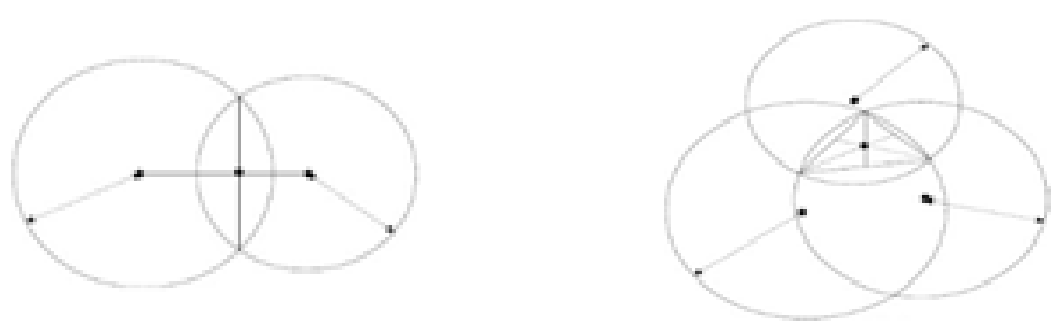

Gambar 3 Metode Lingkaran kasus dua stasiun (kiri) dan kasus tiga stasiun (kanan)

$$
\begin{gathered}
\left(X-X_{1}\right)^{2}+\left(Y-Y_{1}\right)^{2}+\left(Z-Z_{1}\right)^{2}=\left(t_{i}-t_{0}\right)^{2} V_{p}^{2} \\
\left(t_{i}-t_{0}\right) V_{p}=(S-P)_{I} k
\end{gathered}
$$

Dimana :

$$
\begin{array}{ll}
I & =1,2,3, \text { dan } 4 \text { (stasiun ke- } i \text { ) } \\
X, Y, Z & =\text { koordinat sumber gempa yang tidak diketahui } \\
(X, Y, Z) i & =\text { koordinat stasiun seismograph } \\
k & =\text { koefisien jarak yang tidak diketahui } \\
t i & =\text { waktu tiba gelombang } \mathrm{P} \\
t_{0} & =\text { saat terjadinya gempa yang tidak diketahui }
\end{array}
$$

Konstanta jarak $(k)$ adalah merupakan konstanta OMORI :

$$
\begin{gathered}
D=\frac{V p \cdot V s}{V p-V s}(S-P) \\
\frac{V p \cdot V s}{V p-V s}=k
\end{gathered}
$$

Dimana :

$$
\begin{array}{ll}
V_{p} & =\text { cepat rambat gelombang } \mathrm{P} \\
V_{s} & =\text { cepat rambat gelombang } \mathrm{S} \\
D & =\text { jarak hiposenter (sumber gempa) }
\end{array}
$$


$S-P \quad=$ beda waktu tiba gelombang $\mathrm{S}$ dan $\mathrm{P}$

Untuk memudahkan penjelasan, diumpamakan koordinat titik sumber adalah $S$ yaitu $X, Y, Z$. Dan koordinat stasiun diumpamakan titik $H$ yaitu $X i, Y i, Z i$. Dengan kedua koordinat tersebut, dapat dihitung panjang garis $S H$ atau $D$, yaitu :

$$
\begin{array}{cr} 
& S H^{2}=\left(Y-Y_{i}\right)+\left(X-X_{i}\right)^{2} \\
\text { Dan } & D^{2}=S H^{2}+\left(Z-Z_{i}\right)^{2}
\end{array}
$$

$$
D^{2}=\left(X-X_{i}\right)^{2}+\left(Y-Y_{i}\right)^{2}+\left(Z-Z_{i}\right)^{2}
$$

Dengan contoh penurunan rumus diatas, bila digunakan untuk kasus 4 stasiun seismograph, didapat 4 rumusan pula, sebagai berikut:

$$
\begin{gathered}
D_{1}=\left(X-X_{1}\right)^{2}+\left(Y-Y_{1}\right)^{2}+\left(Z-Z_{1}\right)^{2} \\
D_{2}=\left(X-X_{2}\right)^{2}+\left(Y-Y_{2}\right)^{2}+\left(Z-Z_{2}\right)^{2} \\
D_{3}=\left(X-X_{3}\right)^{2}+\left(Y-Y_{3}\right)^{2}+\left(Z-Z_{3}\right)^{2} \\
D_{4}=\left(X-X_{4}\right)^{2}+\left(Y-Y_{4}\right)^{2}+\left(Z-Z_{4}\right)^{2}
\end{gathered}
$$

Analisa dengan cara diatas memerlukan ketelitian pembacaan beda waktu tiba antara gelombang $\mathrm{P}$ dan $\mathrm{S}$, atau lebih dikenal dengan istilah (S-P).

\section{E. Klasifikasi Gempa Gunungapi}

Klasifikasi kegempaan dengan dasar pada klasifikasi Minakami dan Shimozuru dengan beberapa modifikasi. Pada saat ini klasifikasi gempa Merapi yang dipakai bagi pemantauan aktivitas seismik gunung Merapi adalah sebagai berikut:

\section{Gempa Vulkano-Tektonik A = Deep Volcanotectonic Event (VTA)}

Gempa ini berasal dari kedalaman antara 2 sampai 5 kilometer (klasifikasi Minakami menyatakan kedalaman gempa vulkanik A lebih besar dari $1 \mathrm{~km}$ ). Frekuensi dominan gempa, dari analisa frekuensi rekaman seismogram yang tercatat pada elevasi 2625 meter, berkisar antara 5 dan $8 \mathrm{~Hz}$.

\section{Gempa Vulkano-Tektonik B = Shallow Volcanotectonic Event (VTB)}

Gempa jenis ini bersumber pada kedalaman kurang dari 2 kilometer di bawah puncak (klasifikasi Minakami, kedalaman type B kurang dari $1 \mathrm{~km}$ ) dengan impulse pertama yang cukup jelas walaupun kadang-kadang sedikit emergent. Frekuensi dominan gempa berkisar antara 4 dan $7 \mathrm{~Hz}$.

Untuk G. Merapi gempa vulkanik dangkal bisa dibedakan menjadi 4 yaitu:

\section{a. High Frequency Event = Frekuensi Tinggi $(\mathrm{HF}(\mathrm{B}))$}

Gempa vulkanik B dengan `P-onset (pertama)` yang biasanya tegas.

\section{b. Low High Frequency Event (LHF)}

Gempa ini adalah gabungan dari gempa frekuensi rendah (LF) dan gempa frekuensi tinggi (HF).

\section{c. Gempa LF (Low Frequency Event) (FB2, Ratdomopurbo, 1988)}

Gempa ini gempa vulkanik dangkal dengan mempunyai frekuensi dominan sekitar $1.5 \mathrm{~Hz}$ dengan onset cukup jelas. 


\section{d. Gempa MP (Gempa Vulkanik Fase Banyak, MP = Multiphase)}

Gempa MP adalah gempa yang terjadi di kubah lava. Frekuensi dominannya berkisar antara 3 dan $4 \mathrm{~Hz}$.

\section{Tremor}

Tremor di G. Merapi mempunyai frekuensi sekitar 5.7-1.5 Hz, dengan durasi dalam orde menit sampai jam. Di Merapi terdapat dua macam tremor yaitu:

\section{a. Tremor frekuensi rendah}

Tremor frekuensi rendah mempunyai frekuensi dominan $1.5 \mathrm{~Hz}$.

\section{b. Tremor frekuensi tinggi}

Tremor frekuensi tinggi berkaitan dengan kejadian erupsi. Pada saat

\section{Guguran} sebelum letusan, sering tercatat adanya tremor dengan frekuensi tinggi.

Guguran lava atau material dari puncak Merapi yang menuju ke lereng terlihat pada rekaman seismogram sebagai sinyal gempa dengan durasi yang panjang. Amplitudo guguran berkembang dari kecil dan mencapai maksimum setelah lebih dari 15 detik dari awal gempa.

\section{F. GUNUNG MERAPI}

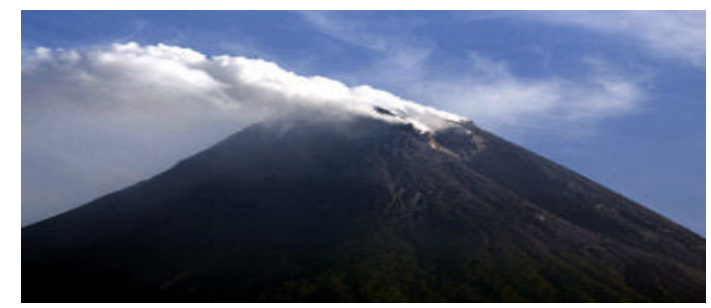

Gambar 4. Gunungapi Merapi

G. Merapi (tinggi $2.978 \mathrm{~m}$, diameter $28 \mathrm{~km}$, luas 300-400 $\mathrm{km}^{2}$ dan volume 150 $\mathrm{km}^{3}$ ) mempunyai tipe gunungapi strato-volcano dengan kubah lava, dibatasi oleh $\mathrm{G}$. Merbabu (2000 m) di utaranya, sedang di sebelah selatannya terletak dataran Yogyakarta. G. Merapi terletak di perbatasan Daerah Istimewa Yogyakarta (Sleman), Kabupaten Magelang, Kabupaten Boyolali, dan Kabupaten Klaten (Jawa Tengah), dengan posisi geografi $7^{\circ} 32,5^{\prime} \mathrm{LS}$ dan $110^{\circ} 26,5^{\prime} \mathrm{BT}$. Aktivitas G. Merapi diperkirakan telah berlangsung sejak 50.000 tahun yang lalu (Berthommier, 1990) dengan kecepatan rata-rata material yang dimuntahkannya dari dalam bumi sebesar $1.000 .000 \mathrm{~m}^{3} /$ tahun.

\section{Sejarah Geologi G. Merapi}

Wirakusumah (1989) membagi Geologi Merapi menjadi 2 kelompok besar yaitu Merapi Muda dan Merapi Tua. Penelitian selanjutnya (Berthomier, 1990; Newhall \& Bronto, 1995; Newhall et.al, 2000) menemukan unit-unit stratigrafi di Merapi yang semakin detil. Menurut Berthommier,1990 berdasarkan studi stratigrafi, sejarah Merapi dapat dibagi atas 4 bagian : 


\section{PRA MERAPI $(+400.000$ tahun lalu)}

Disebut sebagai Gunung Bibi dengan magma andesit-basaltik berumur \pm 700.000 tahun terletak di lereng timur Merapi termasuk Kabupaten Boyolali.

\section{MERAPI TUA (60.000 - 8000 tahun lalu)}

Pada masa ini mulai lahir yang dikenal sebagai Gunung Merapi yang merupakan fase awal dari pembentukannya dengan kerucut belum sempurna.

\section{MERAPI PERTENGAHAN (8000 - 2000 tahun lalu)}

Terjadi beberapa lelehan lava andesitik yang menyusun bukit Batulawang dan Gajahmungkur, yang saat ini nampak di lereng utara Merapi.

4. MERAPI BARU (2000 tahun lalu - sekarang)

Dalam kawah Pasarbubar terbentuk kerucut puncak Merapi yang saat ini disebut sebagai Gunung Anyar yang saat ini menjadi pusat aktivitas Merapi. Sedangkan Merapi yang sekarang ini berumur sSkema penampang sejarah geologi Merapi menurut Berthommier, 1990 (gambar di bawah).

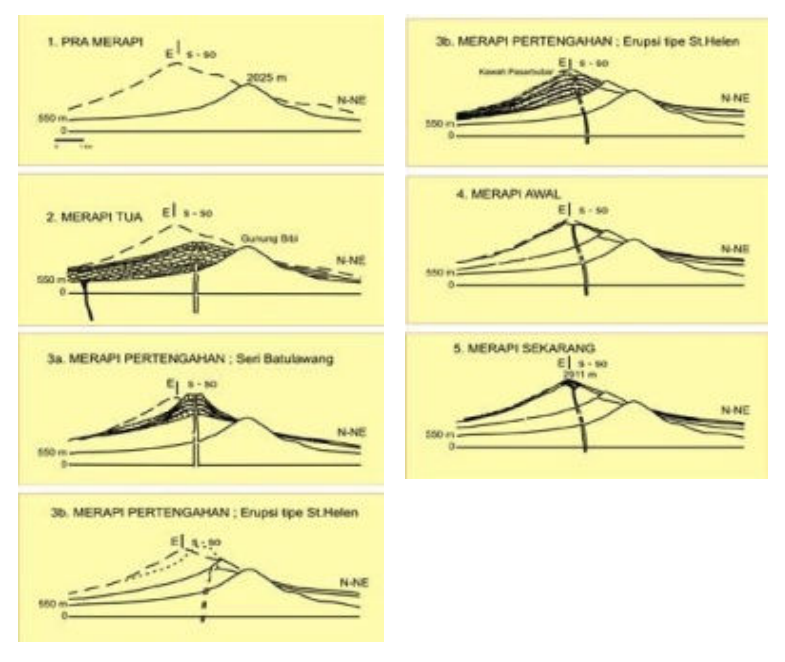

Gambar 5. Sketsa penampang skematik evolusi Merapi sejak jaman Pra-Merapi sampai saat ini menurut Berthommier (1990). (http://merapi.bgl.esdm.go.id/ )

\section{Sejarah Aktivitas G. Merapi}

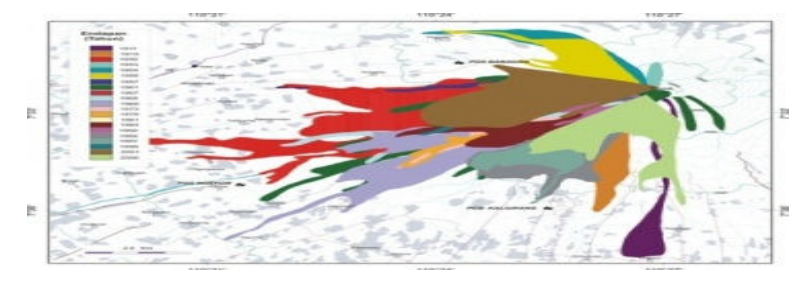

Gambar 6 Peta sebaran endapan awanpanas Merapi 1911-2006 (http://merapi.bgl.esdm.go.id/)

Merapi termasuk gunungapi yang sering meletus. Sampai Juni 2006, erupsi yang tercatat sudah mencapai 83 kali kejadian. Secara rata-rata selang waktu erupsi Merapi 
terjadi antara 2 - 5 tahun (periode pendek), sedangkan selang waktu periode menengah setiap $5-7$ tahun. Merapi pernah mengalami masa istirahat terpanjang selama $>30$ tahun, terutama pada masa awal keberadaannya sebagai gunungapi. Memasuki abad 16 kegiatan Merapi mulai tercatat cukup baik. Pada masa ini terlihat bahwa waktu istirahat terpanjang pernah dicapai selama 71 tahun ketika jeda antara tahun 1587 sampai dengan tahun 1658 .

\section{METODE PENELITIAN}

Dalam penelitian ini menggunakan pendekatan deskriptif, dimana data-data diolah kemudian dijelaskan secara deskriptif.

\section{A. Jenis Data}

Data yang dipergunakan dalam penelitian ini adalah data sekunder dari data hasil rekaman (seismogram) Gunung Merapi pada tahun 2006 yang diperoleh dari Badan Pengembangan dan Penelitian Kegunungapian (BPPTK) - Yogyakarta. Kemudian dilakukan analisa lebih lanjut yaitu mengenai penentuan arrival time dan penentuan sebaran hiposenter gempa vulkanik, hingga penentuan mekanisme sumber gempa dari Gunung Merapi.

\section{B. Alat dan Bahan}

Data dan alat pengolahan data yang digunakan dalam penelitian ini meliputi: Data gempa vulkanik, Microsoft Office Excel 2007, Perangkat lunak yang digunakan disesuaikan dengan pengolahan data yang akan dilakukan, diantaranya: Seismo Volcanalysis, Scream 4.4, Hypoellipse, Matlab.

\section{Metode Penelitian}

Dalam penelitian ini bertujuan untuk menganalisa lebih lanjut mengenai data sinyal gempa vulkanik pada Gunung Merapi. Data yang digunakan adalah data sekunder yang berupa data seismik Gunung Merapi tahun 2006 pada bulan Januari hingga Juni. Metode yang digunakan dalam pengamatan Gunung Merapi salah satunya adalah metode seismik dengan 4 stasiun seismometer yaitu Pusunglondon, Deles, Klatakan, Plawangan. Untuk mempermudah penganalisaan maka dipilih data yang bagus adalah gambaran sinyal yang jelas, S-P dapat dibedakan dengan jelas, dan data tidak terputus pada event.

\section{Pengolahan Data}

Pada penentuan Spectral dan Time Frequency Analysis untuk analisis data seismik digital digunakan software Seismo Volcanalysis. Read data pada Seismo Volcanalysis yang dilakukan mencari folder tempat menyimpan data seismik digital gempa vulkanik dan merubah format data yang digunakan contoh format data gempa berbentuk GCF. Data yang akan digunakan selanjutnya di select dan read file untuk mencari event dari data yang mengalami gempa vulkanik. Pada Seismogram display and data selection akan muncul rekaman data gempa vulkanik yang akan digunakan. Event rekaman seismik digital di select signal to analyze untuk memperjelas rekaman gempa vulkanik. Untuk data processing digunakan pilih menu Spectral dan Time Frequency Analysis. 
Data yang digunakan dalam penelitian ini merupakan data sekunder berupa data gempa vulkanik yang terjadi di G. Merapi pada tahun 2006 yang diperoleh dari rekaman seismogram. Data ini berupa sinyal seismik yang berupa data digital. Selanjutnya pembacaan data ini dapat dilakukan dengan software Scream 4.4.

Kemudian dari software Scream 4.4 akan diketahui rekaman sinyal seismiknya. Pembacaan sinyal ini dilakukan tiap menit untuk mencari event gempa pada tahun 2006. Pada penelitian ini event gempa yang dipilih adalah gempa vulkanik tipe A (VTA) maupun tipe B (VTB). Setelah data-data event telah dikumpulkan selanjutnya dilakukan juga penyeleksian data agar dalam hal menganalisanya mudah, disini dipilih data yang memiliki karakteristik sesuai dengan sinyal yang akan diolah.

Data rekaman seismik yang sudah di picking disimpan dalam notepad dengan format MERAPI.PHA sebagai input data pada program Hypoellipse. Data hasil picking gempa vulkanik yang pada notepad kemudian disimpan dalam format MERAPI.PHA pada program Hypoellipse. Input data tersebut selanjutnya di Run menggunakan Hypoel atau Command Prompt. Pada program Hypoellipse akan menghasilkan data hasil dari Run tersebut yang berupa out file dan sum file.

\section{HASIL DAN PEMBAHASAN}

Gejala awal letusan G. Merapi dapat di lihat dari berbagai data yang menunjukkan peningkatan aktivitas G. Merapi tersebut. Salah satu data yang digunakan untuk melihat peningkatan aktivitas G. Merapi adalah data seismik. Dari data kegempaan di atas gejala awal letusan G. Merapi dimulai dengan munculnya gempa-gempa vulkanik, baik vulkanik dalam (VTA) maupun vulkanik dangkal (VTB) awal Maret 2006 dan puncaknya terjadi pada pertengahan April 2006. Gempa Multiphase (MP) mulai menunjukkan peningkatan sejak awal April 2006 dan mencapai puncaknya pada minggu ketiga April 2006, yang kemudian diikuti dengan munculnya kubah lava baru.

Kubah lava baru muncul ke permukaan pada tanggal 26 April 2006. Pada tanggal 28 April 2006 muncul lava baru sebagai cikal bakal kubah lava yang ditandai dengan munculnya api diam dan guguran lava pijar. Setelah itu terjadi peningkatan guguran lava dan disusul dengan awanpanas kecil yang pertama kali terjadi pada 11 Mei 2006. Awanpanas mengalami peningkatan pada minggu terakhir bulan Mei sampai dengan pertengahan bulan Juni 2006. Dengan jarak luncur antara 1.000-7.000 meter dari minggu pertama bulan Mei sampai dengan pertengahan bulan Agustus 2006 dan jarak luncur terjauh pada tanggal 14 Juni yang mencapai 7.000 meter.Data gempa vulkanik baik VTA maupun VTB tahun 2006 terdapat sebanyak 397 event gempa.

\section{A. Penentuan Spectral dan Time Frequency Analysis}

Untuk mengetahui karakteristik dari gunungapi Merapi dapat dilihat dari spectral and time frequency analysis. Pada gempa vulkanik A frekuensi dominan gempa berkisar antara 5 dan $8 \mathrm{~Hz}$ dengan mempunyai fase $\mathrm{P}$ dan $\mathrm{S}$ yang relatif dapat dibedakan dengan 
jelas. Sedangkan pada gempa vulkanik B dengan frekuensi dominan gempa berkisar antara 4 dan $7 \mathrm{~Hz}$.

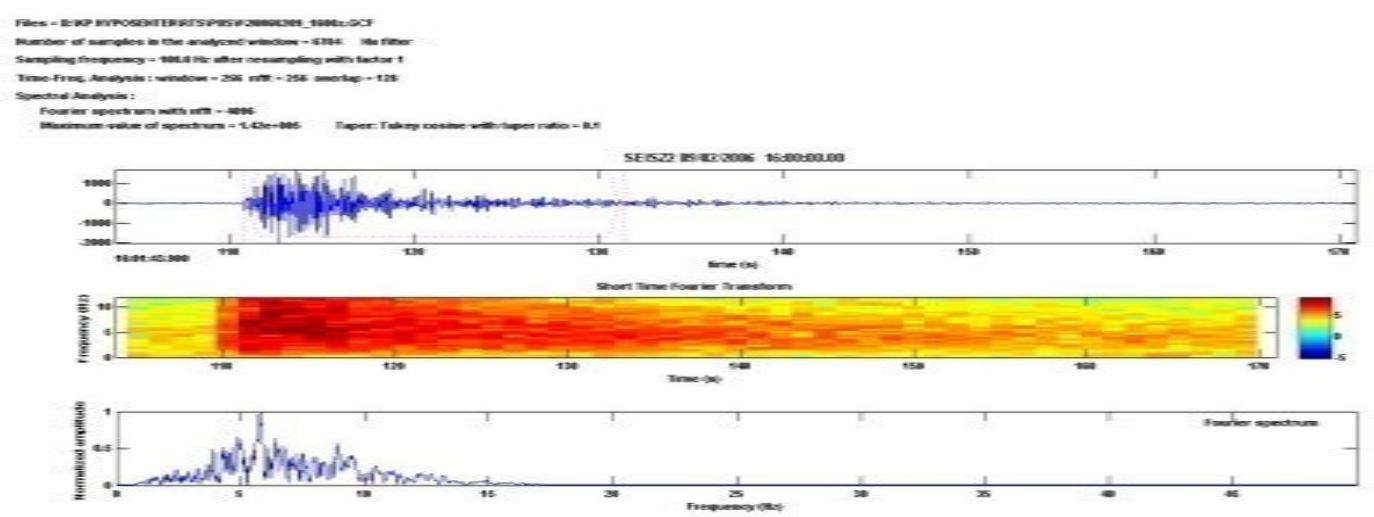

Gambar 7 Hasil pengolahan data dengan software Seismo Volcanalysis

Dari hasil pengolahan data seismik digital dengan software Seismo Volcanalysis diperoleh sampling frequency sebesar $100 \mathrm{~Hz}$. Untuk frekuensi yang diperoleh pada gambar di atas lebih dari $5 \mathrm{~Hz}$. Untuk spectral analysis pada Fourier spectrum with nfft sebesar 4096 dan maximum value of spectrum sebesar $1.42 \mathrm{e}+005$. Picked time: 16:00:55.100 dengan Corresponding amplitudes sebesar 1.5693 (signal) dan -6528 (cursor) sedangkan untuk Picked time and frequency sebesar 50.45 s, $-14.41 \mathrm{~Hz}$.

\section{B. Penentuan Hiposenter}

Sum file pada program Hypoellipse yang berupa notepad disimpan pada Microsoft Office Excel 2007. Data sum file yang sudah dipindahkan dalam Microsoft Office Excel 2007 selanjutnya diolah dengan menggunakan program Matlab 2010. Pada Matlab 2010 data yang dalam bentuk Ms. Excel 2007 di debug dan run yang akan menghasilkan lateral dari hypocenter gempa vulkanik tahun 2006. Berikut adalah gambar hasil ploting hypocenter gempa vulkanik tahun 2006:
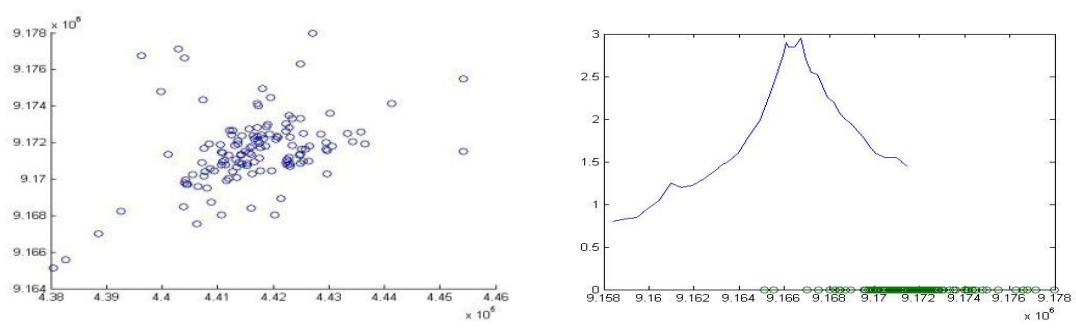

Gambar 8 Hasil Ploting Sebaran Dari Lateral Hypocenter dan Utara-Selatan (NS)
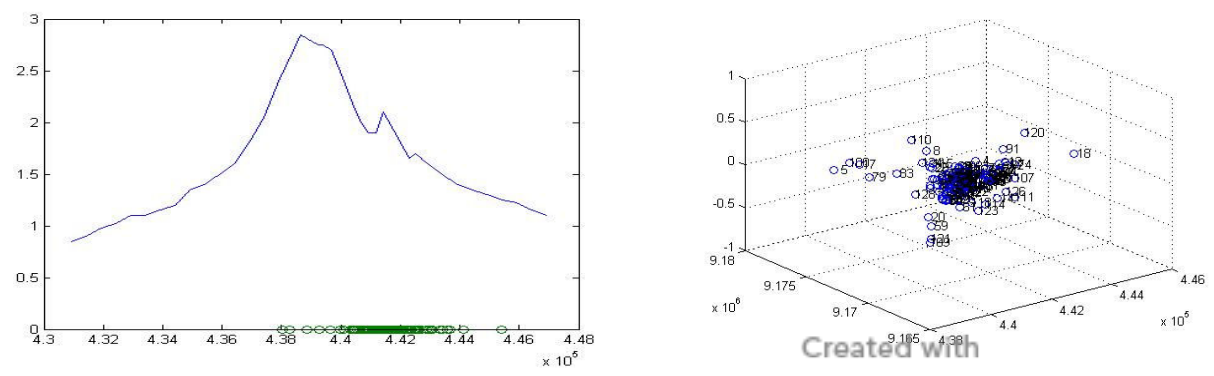
Gambar 9 Hasil Ploting Sebaran Dari Timur-Barat (EW) dan 3 dimensi (3D)

Berdasarkan hypocenter dari beberapa gempa VA dan VB yang terjadi pada tahun 2005/2006, dapat disimpulkan bahwa pusat gempa yang berada pada kedalaman lebih dari $1 \mathrm{~km}$ dari puncak tidak berbeda dengan hypocenter gempa VA dan VB tahun-tahun sebelumnya, tetapi untuk gempa-gempa yang dangkal hypocenter-nya cenderung bergeser ke arah tenggara.

Pada kedalaman 1.5 - $2 \mathrm{~km}$ di bawah puncak tidak dijumpai adanya hiposenter gempa, demikian pula pada kedalaman $>5 \mathrm{~km}$. Gempa volkano-tektonik (VT) memerlukan medium yang solid dan bisa patah (brittle) sehingga zona-zona tidak terdapat hiposenter dianggap zona yang lembek (duktil) karena pengaruh suhu tinggi magma. Dalam proses perjalanan menuju ke permukaan magma memasuki zona tampungan magma, dapat disebut sebagai kantong magma atau dapur magma bila ukurannya lebih besar. Di Merapi terdapat dua zona tampungan magma yang menentukan sifat khas Merapi. Karena letaknya relatif tidak jauh maka kenaikan tekanan di dapur magma akan menyebabkan aliran magma menuju kantong magma di atasnya menyebabkan naiknya tekanan di sana.

\section{Mitigasi Bencana Gunungapi Merapi}

Sebelum tahun 2006, luncuran awan panas hampir selalu mengarah ke barat. Pada tahun 1911-2006, luncuran ini dikontrol morfologi puncak merapi. Dimana di bagian barat terdapat lubang, sedangkan bagian timur terdapat dinding. Disebelah selatan ada sebuah batu besar yang disebut Gegerboyo (punggung buaya), karena mirip dengan punggungan buaya. Memang luncuran juga pernah terjadi kearah selatan, bahkan hingga sangat jauh. Namun secara umum luncuran awanpanas Gunung Merapi ini mengarah ke barat. Pada tahun 1994, awanpanas pernah melanda sebelah barat Lokasi Wisata Kaliurang.

Awan Panas tahun 2006 dinding Gegerboyo ini runtuh sebelum terjadinya gempa Jogja pada 27 Mei 2006 terjadi gempa Jogja dengan kekuatan magnitude hingga 6.3. Keruntuhan geger boyo ini menyebabkan luncuran awanpanas pada erupsi tahun 2006 mengarah ke selatan. Luncuran awanpanas 2010, ketika terjadi luncuran daerah rendahan yang sebelumnya dipakai untuk lewatnya awanpanas terisi oleh material-material yang terbawa tahun 2006, juga hasil endapan lahar yang terangkut oleh air hujan.

Mitigasi yang dilakukan dengan cara sebagai berikut:

1. Pemantauan,aktivitas gunung api dipantau selama 24 jam menggunakan alat pencatat gempa (seismograf).

2. Pemetaan, Peta Kawasan Rawan Bencana Gunung berapi.

3. Penyelidikan gunung berapi menggunakan metoda Geologi, Geofisika, dan Geokimia.

Sosialisasi, petugas melakukan sosialisasi kepada Pemerintah Daerah serta masyarakat terutama yang tinggal di sekitar gunung berapi. 


\section{KESIMPULAN}

Dari penelitian yang telah dilakukan dapat ditarik beberapa kesimpulan sebagai berikut :

1. Munculnya gempa vulkanik merupakan gejala awal letusan G. Merapi yang akan membentuk kubah lava baru di celah antara Gegerbuaya yang selanjutnya akan berpotensi terjadi guguran lava dan awan panas yang yang sangat beresiko bagi masyarakat di sekitar G. Merapi untuk itu diperlukan mitigasi bencana G. Merapi untuk meminimalisir jumlah korban.

2. Gempa vulkanik mempunyai frekuensi dominan antara 4 sampai $8 \mathrm{~Hz}$ dengan amplitudo tidak sama (tidak harmonik) seperti gempa yang lain dan waktu tiba gelombang P-S yang jelas. Jumlah gempa vulkanik pada tahun 2006 sebanyak 397 event gempa.

3. Didapatkan hiposenter yang memiliki kedalaman antara $1 \mathrm{~km}$ dari puncak G. Merapi cenderung ke arah tenggara yang tidak mengalami perubahan dari sebaran hiposenter tahun-tahun sebelumnya. Pada kedalaman tersebut hiposenter G. Merapi bersumber dari aktivitas kantung magma.

\section{DAFTAR PUSTAKA}

Anynomous. 2011. http://merapi.bgl.esdm.go.id/. diakses pada tanggal 25 November 2011 .

Berthommier, P. C. 1990. Etude volcanologique du Merapi (Central-Java): Tephrostratigraphie et chronologie-produit eruptifs, thesis doktoral, Universitas BlaisePascal, Clermont Ferrand. France.

Direktorat Vukanologi. 1992. Kumpulan Karya Ilmiah Hasil Penyelidikan Gunungapi dan Panas Bumi. Yogyakarta.

Hendarjaya, Lilik dan Hendro Laksono. 1990. Pengantar Seismologi. Bandung: Laboraturium Fisika Bumi Jurusan Fisika FMIPA ITB.

Newhall, C.G., Bronto, S. 1995. An Explosive history of Merapi volcano, Merapi De-cade Volcano, International Workshop, Abstract and Program, October.

Newhall, C.G., Bronto, S., Alloway, B.V., Banks, N.G., Bahar, I., Del Marmol, M. A., Hadisantono, R., Andreastuti, S., Tilling, R.I., Torley, R., Trimble, D., Wirakusumah, A.D., 10,000 years of explosive eruptions of Merapi volcano, Central Java: Archaelogical and modern implications, Journal of Volcanology and Geothermal Research (in press).

Ratdomopurbo, A., I. 1988. Pengamatan Seismik dan aktivitas G. Merapi. Bandung: PITHAGI. 
Siswowidjojo, Suparto S. 1981. Seismologi Gunungapi, Metoda pengamatan, Analisa Gempa dan Hubungannya dengan Tingkat Kegiatan Gunungapi. Bandung: Direktorat Vulkanologi.

Tjia, O. M. 1993. Gelombang. Bandung: Jurusan Fisika FMIPA ITB.

Wirakusumah, A.D., Juwarna, H., Lubis, H., 1989. Peta Geologi G. Merapi, Jawa Tengah. Bandung: Direktorat Vulkanologi. 